\title{
Research
Updates
}

\section{A Model for Dry Bean Yield Loss Due to Rust}

\author{
Dale T. Lindgren', \\ Kent M. Eskridge, \\ James R. Steadman ${ }^{3}$, and \\ Daniel M. Schaaf ${ }^{4}$
}

Additional index words. fungicides, loss-model, regression

Summary. Severity of rust (Uromyces appendiculatus) and yield of dry edible beans (Phaseolus vulgaris L.) were recorded for 9 years in west-central Nebraska in fungicidal efficacy trials. A weighted analysis of covariance was used to estimate yield loss due to rust. The model fit the data well $\left(R^{2}=\right.$ $0.94)$, and the slope over all years had a $19 \mathrm{~kg} \cdot \mathrm{ha}^{-1}$ decrease in yield for each $1 \%$ increase in severity of rust. Yield response within years occurred only through reduction of rust for most fungicide treatments.

${ }^{1}$ Professor, Univ. of Nebraska West Central Research Extension Center, North Platte, NE 69101-9495.

${ }^{2}$ Associate professor, Univ. of Nebraska, Dept. of Biometry, Lincoln, NE 68583-0712.

${ }^{3}$ Professor, Univ. of Nebraska, Dept. of Pathology, Lin coln, NE 68583-0722.

${ }^{4}$ Research Technician, Univ. of Nebraska West Central Research Extension Center, North Platte, NE 691019495.

Paper no. 10600, Journal Series, Agricultural Research Division, Univ. of Nebraska, Lincoln. The cost of publish ing this paper was defrayed in part by tbe payment of page charges. Under postal reoulations, this paper therefore must be hereby marked advertisement solely to indicate this fact.
$\mathrm{R}$ ust, caused by Uromyces appendiculatus(Pers. Unger), on dry beans (Phaseolus vulgaris L.) is a production constraint worldwide. Bean yield reductions from rust have been documented to be $18 \%$ to 100\% (Mullins and Hilty, 1985; Stavely and Pastor- Corralos, 1989; ValezMartinez et al., 1989). In humid tropical and subtropical regions, rust can be severe annually, while in humid temperate, and semi-and regions severe disease epidemics are less frequent, but still can cause significant yield reductions. Local weather conditions also play a significant part in determining rust severity and can result in site-to-site and year-toyear variation (Stavely and PastorCorrales, 1989). The prediction of yield losses in dry beans caused by rust is difficult, because differences between years in weather conditions, races of rust, cultivars, types of resistance, crop management, and field location can influence not only the amount of rust but also bean yields in general (Castaño et al., 1986; Mmbaga and Steadman, 1992; Stavely and Pastor-Corrales, 1989).

Uromyces appendiculatum is one of the most variable plant pathogens; therefore, stable plant resistance has been difficult to achieve (Stavely and Pastor- Corrales, 1989). Chemical control is effective, but it increases production and environmental costs. With the need to be competitive, bean growers must have information to manage their crop effectively for maximum yield and minimum financial input. Understanding the relationship of yield with the severity of rust is useful for determining disease management strategies and predicting yield loss potential.

Regression models, used to study and predict yield losses due to disease, require a database of different disease intensities and corresponding crop yields (MeronuckandTeng, 1984; Meronuck, 1987; Shane and Teng, 1987; Teng, 1987). Experiments conducted over several locations and years are essential to obtain a sufficient number of values so that an analysis of covariance (ANCOVA) model with disease intensity as a covariable can be used to predict yield losses (Madden, 1983).

The use of fungicides to develop a range of disease severities is common in plant disease loss studies (Sah and Mackenzie, 1987). There are several precautions that should be considered when using ANCOVA to develop a disease-yield loss model based on combined data from different fungicide trials. Fungicides might provide a positive or negative effect on yield in addition to their direct control of a single disease (Stavely and Pastor-Corrales, 1989). Also, confounding effects with other diseases or other interactions may occur (Sah and Mackenzie, 1987). However, Shane and Teng (1987) state that the main purpose for obtaining pest-yield data is to have an estimate of yield at different levels of pest infestation, not to compare treatments with a control.

The objectives of this study were to 1) use data obtained from fungicidal efficacy trials to develop and evaluate a model to predict yield loss in pinto dry beans due to rust and 2) evaluate the usefulness of this model as it applies to field management decisions.

\section{Materials and methods}

Severity of rust and seed yield of the rust-susceptible bean 'Pinto UI $114^{\prime}$ were collected from fungicidal efficacy trials planted the first week of June at North Platte, Neb., for 9 years (1981-87, 1989, and 1990). 'UI 114' is a medium-maturity cultivar $(90+$ days) that has been grown on the High Plains for the past 25 years. It has been a standard cultivar used in comparing adaptability of newer cultivars and as the susceptible check to compare reaction to rust. Severity of rust was recorded once, 72-75 days after planting, as percent of leaf area visibly covered by sporulating pustules or chlorotic halos surrounding these pustules. The pictorial key published by Stavely (1985) was used as a guide, and defoliation was not a factor in the assessment method. Plots consisted of three rows, six m long, with the center row assessed for disease and harvested for 
yield (expressed as $\mathrm{kg} \cdot \mathrm{ha}^{-1}$ ).

Plots were separated by one spreader row of 'UI114' and sprinkler-irrigated as needed. If no rust pustules were visible by 15 July (just beforeflowering), spreader rows were inoculated with local races of rust and reinoculated at 7-day intervals for 3 weeks. The rust was diluted with $99 \%$ talc and applied as a dust. Plots were sprinkler-irrigated intermittently for brief periods following inoculation. Even with inoculation, severe rust epidemics did not always develop.

Variousfungicideswere tested for rust control efficacy, and nontreated (nonprotected) checks were included for each year. The experimental design each year was a randomized complete block with either four or five replications. Treatments (consisting of fungicide products, timing, number of fungicide applications, and fungicide rates) varied from year to year.

Severity of rust and seed yields were averaged over replicates for each treatment in each year to develop a rust-yield loss model. A weighted analysis of covariance (ANCOVA) on yield with year as the classification factor and rust as the covariate was used. Weights were the number of replicates used for each of the 88 yield means (total of all treatments over years). ANCOVA was used to determine the appropriate shape of the regression lines and if the regression lines differed from year to year. The fit of the model was evaluated with $R^{2}$.

Treatments with high fungicide application rates and the same timing werecomparedwithinthesameyearfor 4yearsusingANOVA.Aprotected LSD was used to determine if treatments affected yield through their influence onseverityof rust only and not because of other factors (e.g., micronutrient content, phytotoxicity) relating to fungicideproduct or rate. The assumption wasthatanydifferencein yields among high-ratefungicidetreatments applied at the same time would be due to factors other than rust inhibition.

\section{Results}

The data used for the ANCOVA model are summarized in Table 1. A linear model to describe the yield responseto severity of rust was adequate because a quadratic response to rust was not significant $(P>0$.05). Slopes didnotdiffersignificantlyamongyears $(P>0.05)$. A slope of- 18.9 that dif- fered from $0(P<0.05)$ was adequate for all years (Fig. 1). There was about a $19 \mathrm{~kg} \cdot \mathrm{ha}^{-1}$ decreaseinyield for each $1 \%$ increaseinseverityofrust,measured 72 to 75 days after planting. The fit of the model was quite good $\left(R^{2}=0.94\right)$.

The intercept for each year was the estimated yield when rust was not present.Yieldintercepts for years were different $(P<0.05)$, varying from lowest in 1984 to highest in 1987. The different intercepts were due to year differences in precipitation, humidity, temperature, wind conditions, and other pests that influence yield.

Fungicide effects on yield other than by control of rust were determined by comparisons of high-rate fungicide treatments with the same application times in 1982, 1985, 1986, and 1987. Only in 1986 were there significant differences in yield between two of the treatments [Mancozeb $(=2798)$ vs. Myclobutanil (60 DF) (=2329)]. These twotreatmentswereappliedatthesame time and in similar amounts, and resultedinsimilarrustseveritybasedon a protectedLSD $(0.05)$ foreachyear(Table 2 ). None of the other high-rate treatments differed significantly in yield.

Rust severity was relatively high in 1981, 1982, 1984, and 1985, and relatively low in 1983, 1986, 1987, 1989, and 1990 (Table 1). In 1983, a low rust year, no measurable precipita- tionwasrecorded in July and August at North Platte, Neb. In the higher rust years (198 1 and 1982), measurable precipitation occurred on 24 days (out of 62 days) in the months of July and August for both years. The other years were intermediate for precipitation. However,monthlymeantemperatures varied considerably among years.

\section{Discussion}

The finding that a $1 \%$ increase in severity of rust, measured 72-75 days after planting, reduced yield by about $19 \mathrm{~kg} \cdot \mathrm{ha}^{-1}$ irrespectiveoftheyear,yield level,orrust severity, was unexpected. Thisfindingisbasedon the observation that the yield-rust regression lines are linear and parallel for all years. In addition, this finding can be interpreted to mean that bean yield is linearly related to the amount of healthy foliage since the yield-rust relationship is linear.

Several cautions should be considered with this model. At lower levels of rust, yield probably is not reduced until a certain threshold of rust is reached. Ablett and Schaafsma (1990) and Woodbury and LeBaron (1959) showed that beans can tolerate a certain amount of photosynthetic leaf area reduction and defoliation before measurable seed yield loss is recorded. Also, at high rust severity, plants defoliate and make it impossible

Table 1. Summary of severity of rust (Uromyces appendiculatus) and yield of dry beans (Phaseolus vulgaris L.) for each of 9 years at North Platte, Neb.

\begin{tabular}{|c|c|c|c|c|c|}
\hline \multirow[b]{2}{*}{ Year } & \multirow{2}{*}{$\begin{array}{c}\text { No. } \\
\text { treatments }\end{array}$} & \multicolumn{2}{|c|}{$\begin{array}{c}\text { Seed yield } \\
\left(\mathrm{kg}^{-h^{-1}}\right)\end{array}$} & \multicolumn{2}{|c|}{$\begin{array}{l}\text { Rust severity }(\%) s \\
\text { (all treatments) }\end{array}$} \\
\hline & & Mean & Range & Mean & Range \\
\hline 1981 & 7 & 2167 & $1694-2468$ & 16.6 & $6.3-46.3$ \\
\hline 1982 & 11 & 2026 & $1649-2346$ & 24.0 & $7.0-45.0$ \\
\hline 1983 & 14 & 1752 & $1229-2129$ & 7.2 & $2.2-16.4$ \\
\hline 1984 & 19 & 1317 & $1011-1733$ & 16.8 & $4.3-43.8$ \\
\hline 1985 & 12 & 1076 & $426-2365$ & 53.1 & $14.5-75.0$ \\
\hline 1986 & 7 & 2377 & $1842-2798$ & 14.1 & $6.4-23.0$ \\
\hline 1987 & 8 & 3380 & $3172-3689$ & 4.2 & $0.5-16.0$ \\
\hline 1989 & 5 & 2991 & $2749-3293$ & 11.4 & $4.0-23.0$ \\
\hline 1990 & 5 & 1541 & $1411-1739$ & 13.8 & $7.0-22.0$ \\
\hline
\end{tabular}

${ }^{z}$ Last number in column also represents rust severity of unprotected treatments.

Table 2. Dry bean (Phaseolus vulgaris L.) yields and severity of rust (Uromyces appendiculatus) for four fungicide treatments at North Platte, Neb., in 1986.

\begin{tabular}{|c|c|c|c|c|c|}
\hline Year & Fungicide & $\begin{array}{c}\text { Application } \\
\text { rate } \\
\left(\mathrm{kg} \cdot \mathrm{ha}^{-1}\right)\end{array}$ & $\begin{array}{l}\text { Application } \\
\text { timing }\end{array}$ & $\begin{array}{c}\text { Yield }^{z} \\
\left(\mathbf{k g} \cdot \mathrm{ha}^{-1}\right)\end{array}$ & $\begin{array}{c}\text { Mean } \\
\text { rust } \\
\text { severity }(\%)\end{array}$ \\
\hline 1986 & Mancozeb & 1.80 & $7 / 28,8 / 11$ & $2798 \mathrm{a}$ & 8.8 \\
\hline 1986 & Myclobutanil (40 W) & 0.07 & $7 / 28,8 / 11$ & $2601 \mathrm{ab}$ & 6.0 \\
\hline 1986 & Myclobutanil $(40 \mathrm{~W})$ & 0.14 & $7 / 28,8 / 11$ & $2508 \mathrm{ab}$ & 5.8 \\
\hline 1986 & Myclobutanil (60 DF) & 0.07 & $7 / 28,8 / 11$ & $2329 \mathrm{~b}$ & 6.4 \\
\hline
\end{tabular}

${ }^{z}$ Mean yields of treatments were compared for each year and application timing separately using a protected LSD (0.05). 


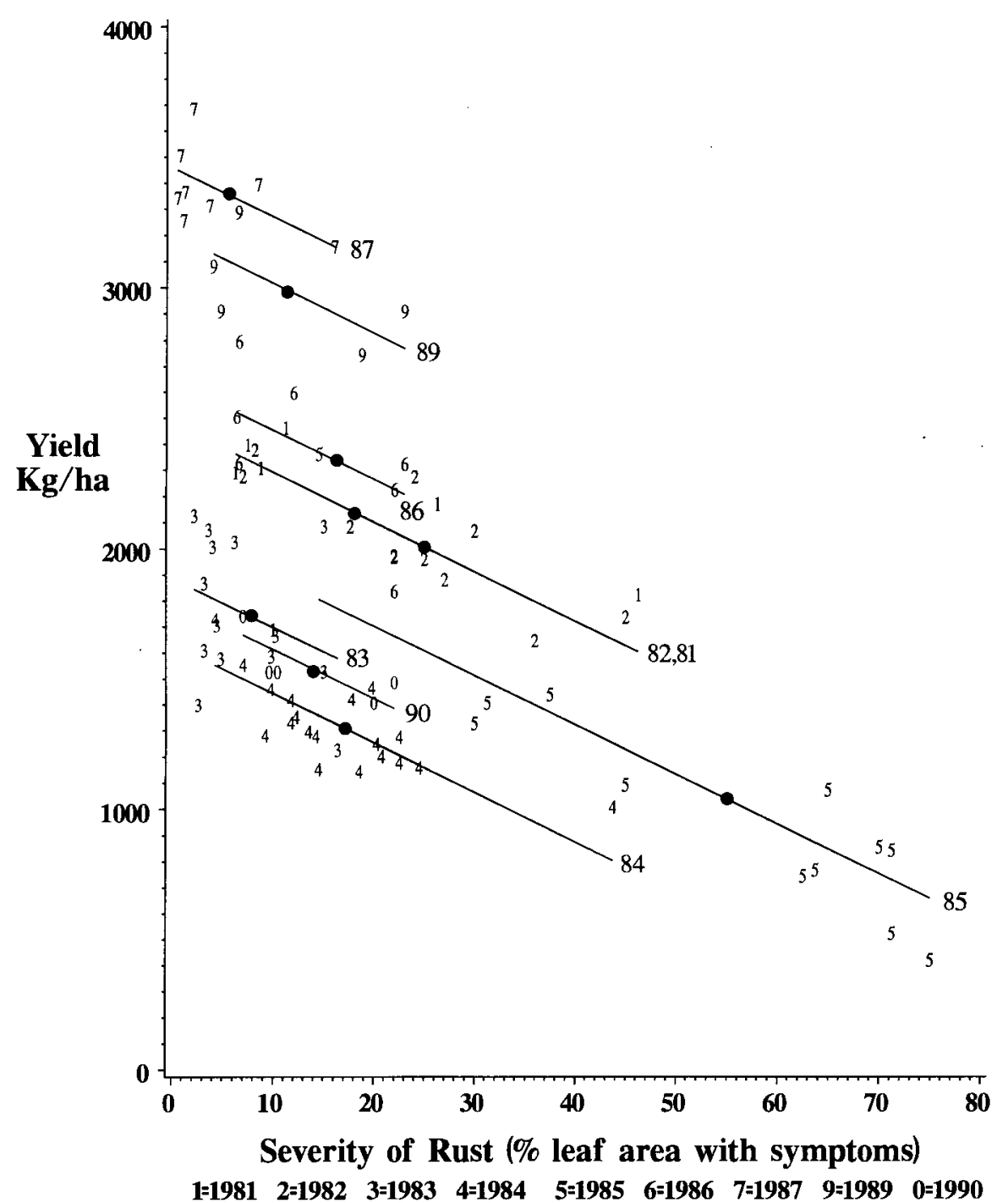

Fig. 1. Bean yields as affected by severity of rust for 9 years at North Platte, Neb. (l)Average rust oper all studies for each year.

to approximate severity of rust based on percent of leaf area diseased. Even with moderate amounts of rust, small differences between treatments cannot always be detected accurately. In addition, the yield increase or decrease due to factors other than disease control could compromise the usefulness of a disease intensity-yield loss ANCOVA model based on disease trials conducted in different environments. Violation of the assumption that treatments affect yield by control of rust severity only would likely cause the slope coefficient and the intercepts for each environment to be biased.

In this study, appropriate comparisons of fungicide treatments were used to show that fungicides influenced yield mainly through the control of rust, although an exception did occur in comparisons between the sterol-inhibiting Myclobutanil (60 DF) and Mancozeb.

\section{Acknowledgements}

The contributions of Leona Barratt for assistance with preparing the figure and David Nuland for suggestions in presenting the information were greatly appreciated.

\section{Literature Cited}

Ablett, G.R. and A. W. Schaafsma. 1990. Effect of defoliation on yield, maturity and seed size of white beans. Bean Improv. Coop. Annu. Rpt. 33:35-36.

Castaño Z., J.C. Anibal Montoya, and M.A. Pastor-Corrales, 1986, In fluencia de el tipo de pastula de roya (Uromyus phaseoli [Reben] Wint) sobre el rend imiento de cultivars de frijol (PhaseoIus vulgaris L). CEIBA 27:321-335.

Madden, L. V. 1983. Measuring and modeling crop losses at the field level. Phytopathology 73:1591-1596.

Meronuck, R.A. and P.S. Teng. 1984. Economic thresholds for chemical control of rust. Phytopathology 74:796.

Meronuck, R.A. 1987. A computer based decision aid for managing bean rust, p. 242-250. In: Crop loss assessment and pest management. APS Press, St. Paul, Min.

Mmbaga, M. T. and J.R. Steadman, 1992. Nonspecific resistance to rust in pubescent and glabrous common bean genotypes. Phytopathology 82:1283-1287.

Mullins, C.A. and J. W. Hilty, 1985. Evaluation of fungicide treatments for control of snap bean rust, Tennessee Home Sci. 135:9-10, Agr. Expt. Sta., Univ. of Tennessee, Knoxville.

Sah, D. N. and D.R. MacKenzie. 1987. Methods of generating different levels of disease epidemics in loss experiments, p. 90-96. In: Crop loss assessment and pest management. APS Press, St. Paul, Min.

Shane, W.W. and P.S. Teng. 1987. Generating the database for disease-loss modeling, p. 82-89. In: Crop loss assessment and pest management. APS Press, St. Paul, Minn.

Stavely, J.R. 1985. The modified Cobb scale for estimating bean rust intensity. Bean Improv. Coop. Annu. Rpt. 28:31-32.

Stavely, I.R. and M.A. Pastor-Corrales. 1989. Rust. VII. In: H.F. Schwartz and M.A. PastorCorrales (eds. ). Bean production problems in the tropics. Centro Intl. Agr. Tropical. Cali, Colombia.

Teng, P.S. 1987. Quantifying the relationship between disease intensity and yield loss, p. 105113. In: Crop loss assessment and pest management. APS Press, St. Paul, Min.,

Velez-Martinez, H., J. Lopez-Rosa, and G. F. Freytag.1989. Determination of yield loss caused by rust [( Uromyces phaseoli [ Reben] Wint. ) in common bean (Pbaseolus vulgaris L.) in Puerto Rico. Bean Improv. Coop. Annu. Rpt. 32:134135.

Woodbury, G.W. and M. LeBaron. 1959. A study of simulated hail injury in beans. Idaho Agr. Expt. Sta. Bul. No. 322. 